\title{
Editorial
}

\section{The concept of abuse of law}

\author{
Yann Kergall, Bureau Francis Lefebvre, Neuilly-sur-Seine, France
}

The concept of 'abuse of law' is indeed one of those concepts on which 'civil law' countries and 'common law' countries may appear to be in conflict.

In civil law countries, the combination of statutory rules and prescribed legal forms have aroused the imagination of law users, allowing them to break new ground and make use of the law to overturn its ends.

To combat effects not intended by the legislator, such countries have been the first to give a legal definition of the abuse concept. Such definition refers, as the case may be, to sham, fraud, or independent interpretation. Specific procedures have had to be set up in order to ensure the enforcement of the law itself (France, Germany).

Traditionally, in common law countries, the tax legislation has not laid down any 'anti-avoidance' rule, nor has it cared to spell out the principle that the substance of a transaction must be given precendence over its form. It was first the legislator who reacted by plugging loopholes exploited by schemes, not ruled out under the law but which resulted in tax revenue losses. A further reaction by the courts followed, in particular the United Kingdom courts since 1981 (Ramsay (W.T.) Limited v. URC), whereby advantageous tax consequences of artificial transductions which had no other purpose than tax avoidance or reduction were eliminated.

As tax treaties proliferated, new possibilities developed which certain States, the United States in the first place, have decided to fight in order to protect their tax revenues and avoid that such treaties be used by non residents of the treaty partner not intended to benefit from them. Tax treaties have therefore begun incorporating anti-shopping provisions aimed at counteracting a new form of abuse of law.

Is it now possible to consider that such concepts stemming from different legal traditions may converge, and, if so, how?

By paralleling in this issue analyses of the concept of abuse of law made by various countries, Intertax has tried to give up-to-date answers to such questions.

Beyond their scientific interest, such answers, although still somewhat qualified, have more and more influence on national and international as well as business practice.

How, for instance, could it be possible to take advantage, as may be lawfully done, of a qualification of a same transaction varying from one country to another, with requalification hovering like an unpredictable menace, capable of disrupting a posteriori economic operations stretching out over several years?

How to keep arm's length transactions secure, if prior advice sought from experts is subordinated to unreliable or too uncertain concepts of abuse of law, or of substance precedence over form?

How could doctrines, possibly converging, be applied by courts of foreign countries ignoring each other?

Beyond the uncertainties on which Intertax editors have tried to enlighten their readers, two basic rules could be usefully reminded:

- where tax savings is the sole or the predominant purpose of a transaction, such transaction is risky and should be advised against,

- conversely, if the transaction is founded on a predominant and undisputable actual economic motive, the taxpayer who has chosen the most tax-effective solution has to be protected.

It goes without saying that Intertax cannot ignore this development. Therefore, the next issue will be dedicated to the 'Abuse of law'. 